\title{
The potential of ruminants for the utilization of fibrous low-quality diets
}

By W. v. Engelhardt, D. W. Dellow a and H. Hoeller, Department of Physiology, School of Veterinary Medicine, Bischofsholer Damm 15, D-3000 Hannover I, Federal Republic of Germany

The continuously-increasing demand for food by a steadily-growing human population has created strong competition between man and animals for certain feedstuffs that can be used by both. Rations used for intensive beef and milk production are largely based on grain, which is the staple food for man in most of the developing countries with a general protein-energy deficiency (Lapedes, 1980). It has been estimated that in 1990 there will be a deficiency of grain for human consumption in the order of 100 million tonnes. At present, approximately $40 \%$ of the world's total grain production is used in the industralized countries, which contain $20 \%$ of the world's human population, and $60 \%$ of this grain is given to animals. Only $15 \%$ of total grain used in animal feeding goes into animal production in developing countries (Byerly, $1978 ;$ Dale, 1979 ).

There seems to be another argument against intensive animal production now and in the future. The efficiency of conversion of dietary components to animal products is generally very low. The conversion of dietary crude protein to animal protein is $22-25 \%$ in egg, milk and poultry production but as little as $4-5 \%$ in beef and mutton production. Energy conversion rates are equally poor (Janick et al. 1976). So the question has to be raised whether such low conversion efficiencies will really permit animal production in the future.

On the other hand, only about $11 \%$ of the world's land surface is arable land; of the remainder, $23.5 \%$ is permanent pasture, $32.4 \%$ forest and woodlands, and $34.3 \%$ other land (Crabbe \& Lawson, 1981). Approximately, only half the dry matter harvested from arable land can be directly used for human consumption. The other half, together with material drawn from pastures and 'other land' (together more than $50 \%$ of land surface), can be utilized for feeding herbivorous animals. Such material includes fibre, by-products and waste from processing human food, protein of extremely-low value, and non-protein-nitrogen compounds. The enormous advantage lies in the fact that material unfit for human consumption can be converted into high-quality animal protein although the conversion efficiency is generally low. Millions of tonnes of crude fibre are available for animal use but only a small part of it is actually consumed. Unfortunately cellulose is often incorporated into indigestible lignin structures thus reducing overall cellulose utilization (Van Soest, 1982). The digestibility of various lignified materials by ruminants can be increased by chemical treatment (Klopfenstein et al.

- Present address: DSIR, Applied Biochemistry Division, Palmerston North, New Zealand. 
1972; Gihad et al. 1980). Such treatments are technically simple and do not require great investments. The procedure which is already wide-spread, e.g. in Norway, Ireland and Canada, offers means of making use of cellulose-rich by-products and waste-products so far not utilized by domestic livestock.

The maximal rate of microbial digestion of plant cell walls in the digestive tract is set by intrinsic characteristics of the cellulose-hemicellulose complex (Smith et al. 1971). However, even under conditions of adequate energy and $\mathrm{N}$ supply this fermentation is relatively slow. Thus, the extent of fibre digestion depends on the size of the fermentation chamber and the flow rate of digesta.

\section{Fibre digestion in foregut and hind-gut fermenters}

As shown by Van Soest et al. (1983), the capacity for cellulose digestion is different for different species of herbivores and omnivores. Foregut fermenters digest cellulose more efficiently than do hind-gut fermenters (Fig. I). The smaller hind-gut fermenters digest cellulose less efficiently than larger animals. Amongst foregut fermenters fed on comparable diets this relationship is not obvious. However, for the very small ruminants information on cellulose digestibility is not available.

\section{Capacity of fermentation chambers in herbivores}

It has been shown by Van Soest et al. ( 1983 ) that cellulose digestibility increases with mean retention time in the digestive tract and that, compared with other species, foregut fermenters have longer retention times and, hence, high cellulose digestibilities. Demment \& Van Soest (1982) have plotted log of the weight of gut contents of ruminating and non-ruminating herbivores $v$. log of the body-weight, ranging from 0.01 to $10000 \mathrm{~kg}$. Two of their findings are of relevance in this context: (a) small animals have smaller gut volumes per kg body-weight, explaining lower cellulose digestibilities observed in non-ruminants; (b), the larger foregut and hind-gut fermenters have similar gut volumes per $\mathrm{kg}$ body-weight, thus excluding different gut size as a factor responsible for better digestibility in foregut fermenters.

However, as noted by Van Soest (1982), regression values for this type tend to overlook disparate characteristics of individual species. According to Kay et al. (1980), ruminants that are predominantly grazers have a more voluminous reticulo-rumen than have browsers and concentrate selectors. Therefore, grazing ruminants or roughage eaters are more efficient in utilizing fibrous diets compared with concentrate selectors (Prins et al. 1983). Particularly the very-small African browsing ruminants have a small rumen capacity and a more rapid turnover of digesta (Kay et al. 1980), thus their capacity for cellulose digestion is likely to be low; detailed studies with comparable diets have, however, not been reported. It may be of interest in this respect that in macropodine marsupials fed on the same roughage diet, digestion of cellulose was similar in small $(5 \mathrm{~kg})$, browsing and grazing species and in a larger ( $19 \mathrm{~kg}$ ) grazing species (Dellow \& Hume, 1982). 


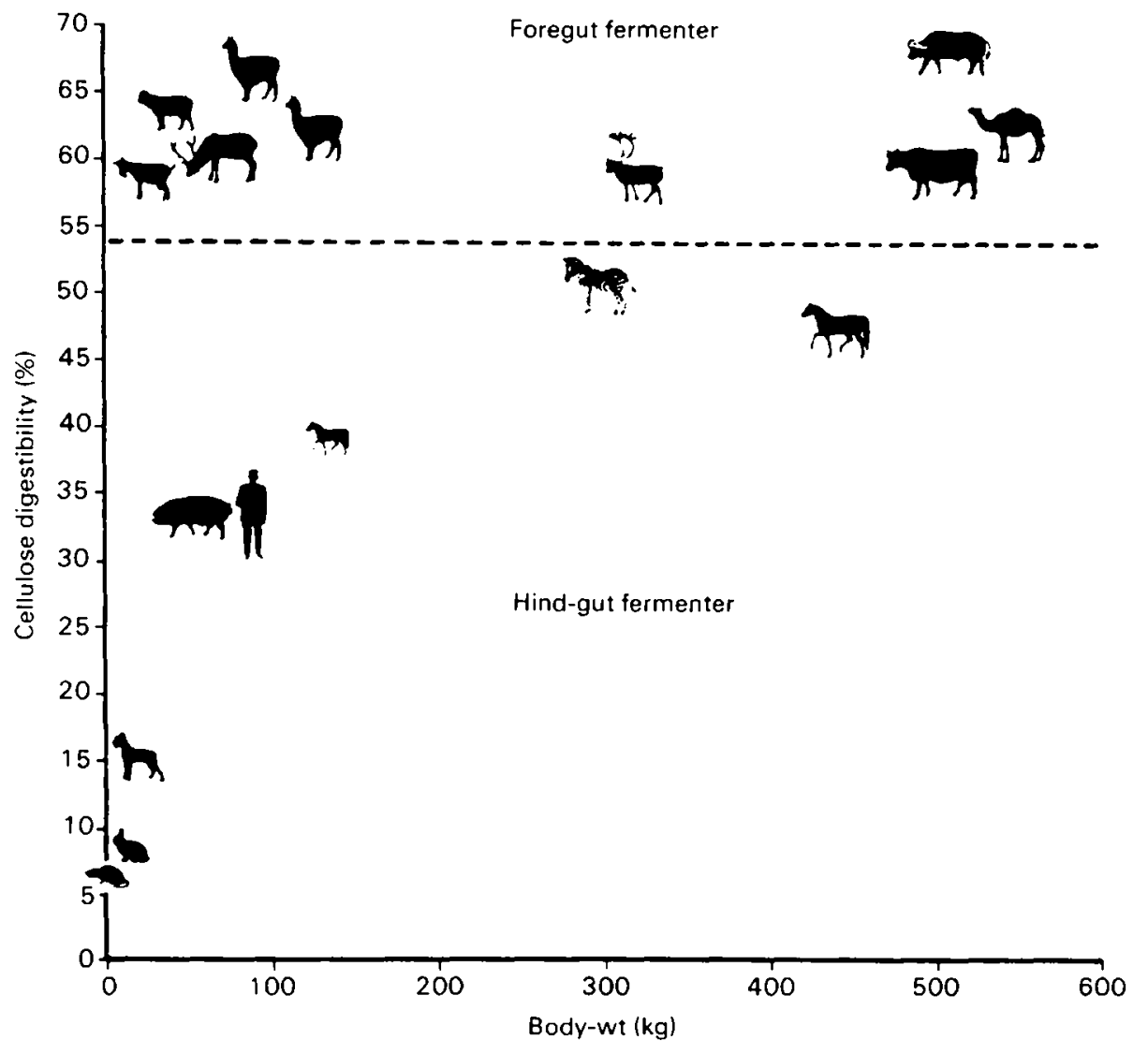

Fig. I. Cellulose digestibility in relation to body-weight in foregut fermenters and in hind-gut fermenters. Foregut fermenters depicted are: goat, sheep, red deer, llama, caribou, cattle, buffalo, camel; only values from animals fed on diets of comparable roughage content were considered. Hind-gut fermenters depicted are: rat, rabbit, dog, pig, man, pony, zebra, horse; diets for hind-gut fermenters varied widely in roughage content. Values are from Van Soest ( 1982 ) and Engelhardt \& Schneider (1977).

Very little is known about adaptation of the reticulo-rumen volume to changing feeding conditions. In preliminary studies in our laboratory with an autochthonous breed of sheep from northern Germay (Heidschnucken) and with Merino sheep, rumen fluid volumes were measured after adaptation to high-fibre diets. After 2 weeks of heather grazing, rumen fluid volumes in Heidschnucken increased from 14 to $22 \%$ of body-weight and in Merinos from 9 to $14 \%$ of body-weight. When wheat straw was the major dietary component for the Heidschnucken over a 5 -month period the mean rumen fluid volume increased to $32 \%$ of body-weight which itself remained constant (Weyreter \& Engelhardt, 1984). This is much beyond the upper values of $20 \%$ of body-weight normally accepted for ruminants (Van Soest, 1982). 


\section{Selective retention of feed particles in foregut fermenters}

Another strategy of digestion of cell wall components is the selective retention of feed particles in the forestomach. In camels, llamas, sheep and macropodine marsupials fed on roughage diets (Table $\mathrm{r}$ ), particles are retained in the forestomach considerably longer than fluid. However, in the hind-gut fermenters particles are not selectively retained in the large intestine. In the caecum and in the large bowel of the horse, the retention time of particles is only a quarter of that in the reticulo-rumen of heifers. Accordingly, crude fibre digestibility is lower in horses than in cattle (Demment \& Van Soest, 1982) or sheep (Jarrige, 1980). On the other hand, in the rabbit, particles pass rapidly through the large intestine (Bjönhag, 1972; Pickard \& Stevens, 1972) resulting in a low fibre digestibility, even though the fluid is retained for a very long time.

In sheep (Demment \& Van Soest, 1982; Ulyatt, 1983) and in steers (Ellis et al. 1979), most feed particles longer than $500 \mu \mathrm{m}$ do not leave the rumen. As early as I 960 Rodriguez \& Allen ( 1960 ) showed in experiments with cows that lucerne (Medicago sativa) hay ground to a particle size of $280 \mu \mathrm{m}$ had a mean retention time in the reticulo-rumen of $27 \mathrm{~h}$, and fibre digestibility was only $28 \%$. Long hay was retained for $54 \mathrm{~h}$ with a fibre digestibility of $44 \%$.

The decrease in size of longer particles in the rumen occurs mainly during rumination, microbial action alone does not greatly contribute to reduction in particle size (Ulyatt, $19{ }^{8} 3$ ). It appears that large particles are not able to flow from the reticulo-rumen until reduced to a minimal size. This results in longer retention within the reticulo-rumen and limits the ruminant's intake. Most likely two major factors limit the intake of highly fibrous diets: (a) the rate of breakdown of the longer fibrous constituents to small particles, and (b) the rate of selective removal of resultant small particles from the reticulo-rumen. In hind-gut fermenters this limitation to larger particle size flow does not exist, and it obviously does not limit the intake to a great extent.

Table I. Retention time of liquid and of particles in the forestomach of foregut fermenters and in the caecum and large bowel of hind-gut fermenters

\begin{tabular}{|c|c|c|c|c|}
\hline \multicolumn{4}{|c|}{$\begin{array}{l}\text { Retention time in fermentation } \\
\text { compartment }(\mathrm{h})\end{array}$} & \\
\hline & & Liquid & Particles & Reference \\
\hline \multicolumn{5}{|c|}{ Foregut fermenters } \\
\hline Camels & 500 & 18 & 64 & R. Heller (unpublished results) \\
\hline Large heifers & 555 & I 5 & 47 & Van Soest ( 1982 ) \\
\hline Small heifers & 243 & 16 & $3^{8}$ & Van Soest (I982) \\
\hline Llamas & 130 & I 5 & 30 & Heller $(1983)$ \\
\hline Sheep & 30 & 19 & 35 & Van Soest (1982) \\
\hline Goats & 29 & 19 & 28 & Van Soest ( 1982 ) \\
\hline Wallabies & 4 & 4 & 16 & Dellow $(1982)$ \\
\hline \multicolumn{5}{|c|}{ Hind-gut fermenters } \\
\hline Horses & 388 & 11 & 10 & Van Soest (1982) \\
\hline Ponies & 132 & 9 & 10 & Van Soest (I982) \\
\hline Rabbits & 3 & 180 & 4 & Van Soest ( 1982$)$ \\
\hline
\end{tabular}


The mechanisms causing extended retention of food particles in the forestomach are not yet fully understood. Two major factors seem to be involved, the uneven distribution of particles within the reticulo-rumen and the motility of the reticulo-omasal canal. Larger particles tend to be retained in the dorsal sections of the rumen. Only digesta from the ventral region of the reticulum is presented to the orifice as it opens during the motility cycle. At that time the canal relaxes, and contents are sucked into the canal (Stevens et al. 1960; Ehrlein \& Hill, r 969). The claw-shaped papillae at the orifice may entrap larger particles. The distal region of the canal then relaxes, and the proximal part contracts. This has the effect of rejecting some contents back into the reticulum (Ehrlein, 1980); this may be effective in flushing entrapped larger particles from the claw-shaped papillae. The remaining material passes into the distal region of the canal and is finally pumped into the omasum. The fact that this material has a $30 \%$ lower dry matter content then rumen digesta (Hauffe \& Engelhardt, I975) supports this hypothesis.

Particles are also selectively retained in the omasum but due to the considerably lower microbial activity (Giesecke \& Engelhardt, 1975) fibre digestion in the omasum may not be significant.

\section{Strategies in future animal production}

In the light of competition for certain feedstuffs between man and animals, a re-evaluation of animal production has to be made on the basis of that proportion of the diet which can also be used by man. Bywater \& Baldwin (1980) have made such an evaluation based on production practices common in California.

Different proportions of total digestible protein input are made up by protein edible by man if milk, beef, pork and poultry are compared. If the efficiency of production is expressed in terms of human edible protein return as a percentage of total digestible protein input pork, poultry and milk production have efficiencies of $29-38 \%$ and beef production of only $5 \%$. However, the picture is entirely different if human edible protein return is expressed as a percentage of input of digestible protein edible also by man. The efficiencies are $181 \%$ for dairy cattle, $109 \%$ for beef cattle, $86 \%$ for pork and $75 \%$ for poultry production. This example shows that a more appropriate approach towards animal production efficiency is made by differentiating between feeds exclusively utilizable by animals and such materials which can also be consumed by man.

\section{Conclusion}

In many countries, especially in those with high average incomes, the demand for animal products will continue but high production levels are often only reached when feedstuffs with a high protein and energy density are used. This results in increasing competition between man and animals for high-quality crop products.

The task will be to maintain the world's demand for high-quality animal products. However, a future animal feeding concept should be based on feed resources that are plentiful and cheap but not usable for man, such as fibrous plant materials, by-products, and waste non-protein-N. Most probably feedstuffs also 
edible by man will not be entirely excluded from animal diets but their proportion will be greatly reduced.

The evaluation of feed conversion efficiencies has to be modified. If only that portion of a given animal diet is considered that can also be eaten by man, conversion efficiencies are particularly high for milk and beef production. That fact is mainly due to the high fibre utilization in the forestomach. This underlines the significant future role of ruminating animals in animal production. Such changes in animal feeding strategy will necessarily result in lower individual production rates. It will be a great challenge to animal geneticists and animal breeders to provide ruminants that make optimal use of low-quality fibre diets in the future.

Financial support for this work was provided by grant En65/1 i of the Deutsche Forschungsgemeinschaft.

\section{REFERENCES}

Bjornhag, G. (1972). Swedish fournal of Agricultural Research 2, $125^{-1} 3^{6 .}$

Byerly, T. C. (1978). In New Protein Foods, pp. 72-1 15 [A. M. Altschu and H. L. Wilcke, editors]. New York: Academic Press.

Bywater, A. C. \& Baldwin, R. L. (1980). In Animals, Feeds, Foods and People, pp. 1-30 [R. L. Baldwin, editor]. Boulder, Colorado: Westview Press.

Crabbe, D. \& Lawson, S. (1981). The World Food Book, New York: Nichols Publishing Co.

Dale, M. B. (1979). World Animal Review 32, 42-48.

Dellow, D. W. (1982). Australian Journal of Zoology 30, $75 \mathrm{t}-765$.

Dellow, D. W. \& Hume, I. D. (1982). Australion fournal of Zoology 30, 399-406.

Demment, M. W. \& Van Soest, P. J. (1982). Cited by Van Soest (1982).

Ehrlein, H.-J. (1980). Film $\mathrm{C}_{1328}$. Institut für Wissenschaftlichen Film, Göttingen.

Ehrlein, H.-J. \& Hill, H. (1969). Zentralblatt für Veterinämedizin 16, 573-596.

Ellis, W. C., Matis, Y. H. \& Lascano, C. (1979). Federation Proceedings 38, 2702-2706.

Engelhardt, W. v. \& Schneider, W. (1977). Animal Research and Development 5, 68-72.

Giesecke, D. \& Engelhardt, W. v. (1975). Zentralblatt für Veterinärmedizin 22, 177-1 86.

Gihad, E. A., El-Bedawy, T. M. \& Mehrez, A. Z. (1980). Journal of Dairy Science 63, 1701-1 706.

Hauffe, R. \& Engelhardt, W. v. (1975). Zentralblatt für Veterinärmedisin 22, 149-163.

Heller, R. (1983). Vormagenmotorik und Passage von festem und flussigem Inhalt durch die Vormagen des Lamas. PhD thesis, der Universität Hohenheim.

Hömicke, H. \& Björnhag, G. (1980). In Digestive Physiology and Metabolism in Ruminants, pp. 707-730 [Y. Ruckebusch and P. Thivend, editors]. Lancaster: MTP Press Ltd.

Janick, J., Noller, C. H. \& Rhykerd, C. L. (1976). Scientific American 235, 75-86.

Jarrige, R. (1980). In Digestive Physiology and Metabolism in Ruminants, pp. 763-823 [Y. Ruckebusch and P. Thivend, editors]. Lancaster: MTP Press Ltd.

Kay, R. N. B., Engelhardt, W. v. \& White, R. G. (Ig80). In Digestive Physiology and Metabolism in Ruminants, pp. 743-761 [Y. Ruckebusch and P. Thivend, editors]. Lancaster: MTP Press Ltd.

Klopfenstein, T. J., Krause, V. E., Jones, M. J. \& Woods, W. (1972). Fournal of Animal Science $35,418-422$.

I apedes, D. N. (1980). Food, Agriculture and Nutrition. New York: McGraw-Hill Book Co.

Pickard, D. W. \& Stevens, C. E. (1972). American fournal of Physiology 222, 1 161-1166.

Prins, R. A., Rooymans, T. P., Veldhuizen, M., Domhof, M. A. \& Cline-Thiel, W. (1983). Zoologische Garten N.F. 53S, 393-403.

Rodriguez, C. B. \& Allen, N. N. (1960). Canadian fournal of Animal Science 160, 23-29.

Smith, L. W., Goering, H. K., Waldo, D. R. \& Gordon, C. H. (1977). Fournal of Dairy Science 54, $71-76$. 
Stevens, C. E., Sellars, A. F. \& Spurrell, F. A. (1960). American fournal of Physiology 198, 449-455.

Ulyatt, M. J. (1983). In Fibre in Human and Animal Nutrition, pp. 103-107 [G. Wallace and L. Bell editors]. Wellington, New Zealand: Royal Society of New Zealand.

Van Soest, P. J. (1982). Nutritional Ecology of the Ruminant. Corvallis, Oregan: O \& B Books Inc. Van Soest, P. J., Jeraci, J., Foose, T., Wrick, K. \& Ehle, F. (1983). In Fibre in Human and Animal Nutrition, pp. 75-80 [G. Wallace and L. Bell, editors]. Wellington, New Zealand: Royal Society of New Zealand.

Weyreter, H. \& Engelhardt, W. v. (1984). Canadian fournal of Animal Science 64, 152-153. 